\title{
Kolon polipleri ve diyet ilişkisi
}

\author{
Relationship between colon polyps and diet
}

\author{
Yasin ŞAHINTÜRK, Ayhan Hilmi ÇEKIN \\ Sağlık Bilimleri Üniversitesi Antalya Sağlık Uygulama Araştırma Merkezi, İç Hastalıkları Kliniği, Gastroenteroloji Kliniği, Antalya
}

\begin{abstract}
Giriş ve Amaç: Diyet alışkanlıkları ve spesifik besin gruplarının kolon polip gelişimi, histolojisi ve boyutları üzerindeki etkisinin aydınlatılması. Gereç ve Yöntem: 2012-2015 yılları arasında kolonoskopi yapılan 1004 hasta beslenme alıskanlıkları yönünden prospektif olarak değerlendirildi. Hastalar kolon polibi var-yok, kolon polibi olanlar ise hiperplastik-adenomatöz, $<1 \mathrm{~cm}->1 \mathrm{~cm}$ olarak sınıflandırıldı ve gruplar arası diyet alışkanlıklarının farkları incelendi. Bulgular: Çalışmamızda kolon polip gelişmesini; yaş, erkek cinsiyet, kırmızı et ve bulgur tüketimi arttıırken, domates tüketimi azaltmaktadır. Adenomatöz histoloji görülme sıkığını artıran faktörler yaş ve bulgur tüketimi olarak saptanırken; azaltan faktörler ise yumurta ve pirinç tüketimindeki artış olarak saptanmıştır. Kolon polip boyutlarını ise sadece bulgur tüketimindeki artışın etkilediği saptanmıştır. Sonuç: Kolonda polip gelişimi, adenomatöz histoloji varı̆̆ı ve 1 cm'den büyük polip gelişimi şeklinde bu üç kolorektal kanser risk faktörünü de artıran tek besin maddesi bulgur olarak saptanmıştır. Bulgurun tüketim şekli, sıklığı ve kolon kanseri saptanan hastaların geçmiş dönemdeki bulgur tüketimleri ayrıntılı sorgulanmalı ve konuyla ilgili daha ayrıntılı çalışmalar yapılmalıdır.
\end{abstract}

Anahtar kelimeler: Kolon polip, diyet, polip boyutu, polip histolojisi, spesifik besin ürünleri

\section{GíRiş}

Epitelyal yüzeyden doğan bir çıkıntı anlamında kullanılan polip; kalın barsak mukozasının anormal büyümesi sonucu mukozadan tomurcuklanan ve lümene doğru gelişen kabarıklıklardır. Kolon lümeninde gelişip gizli olarak büyüyen polipler saplı olup olmamasına, boyutlarına, sayılarına ve histolojik özelliklerine göre değerlendirilirler. Neoplastik olanlar ve olmayanlar olarak iki ana başlık altında incelenirler. Neoplastik olanlar adenomatöz polipler ve karsinomlar olup neoplastik olmayanlar ise hiperplastik polip, inflamatuvar polip ve hamartomatöz poliplerdir $(1,2)$.

Kolorektal kanser (KRK) dünyada 3. en sık ölüm nedenidir (2). Sanayileşmiş ülkelerde daha sık görülen KRK, kansere bağlı ölümlerde 2. sırada yer alması nedeniyle önemli bir sosyal ve sağlık konusudur $(1,2)$. Polipler KRK gelişmesinde risk faktörü olmalarına rağmen her polipten
Background and Aims: The aim of this study was to identify the effect of dietary habits and specific nutrient groups on colon polyp development, histology, and size. Materials and Methods: Between 2012 and 2015, 1004 patients who underwent colonoscopy were evaluated prospectively for their dietary habits. Patients were classified according to whether or not they had colon polyps. Patients with polyps were classified as hyperplastic-adenomatous, $<1 \mathrm{~cm}->1 \mathrm{~cm}$ and differences in dietary habits among the groups were examined. Results: In our study, colon polyp development decreased by tomato consumption whereas increasing age, male sex, red meat, and bulgur consumption increased development. While factors increasing the incidence of adenomatous histology were determined as age and bulgur consumption, the decrease was observed after an increase in egg and rice consumption. It was concluded that colon polyp diameter is only affected by bulgur consumption. Conclusion: The only nutrient that increases the risk of developing colonic polyps, which are larger than $1 \mathrm{~cm}$ in diameter, and have adenomatous histology, is bulgur. The type and frequency of consumption of bulgur should be questioned in detail, and additional studies on this subject that are more comprehensive should be performed.

Key words: Colon polyp, diet, polyp size, polyp histology, specific nutritional products

kanser gelişmesi beklenmez. Özellikle 1 cm'den küçük tübüler adenomların (villöz özellik veya displazi içermeyen) kanser gelişimindeki klinik önemi aydınlatılmış değildir. Genel olarak kolon kanserlerinin tamamı adenomatöz poliplerden gelişmesi nedeniyle kolon ve rektumdaki adenomların gelişimini önlemek veya tespit edildiklerinde çıkarmak KRK'den korunmada önemli bir basamaktır (3). Bu nedenle kolorektal poliplerin gelişimini önlemeye yönelik daha fazla araştırma yapılmalıdır. Yapılan uluslararası çalışmalarda çevresel faktörlerin, özellikle diyet alışkanlıklarının kolon polip gelişmesinde önemli rolü olduğu vurgulanmıştır $(4,5)$. Kolon poliplerinin gelişmesinde diyet alışkanlıklarının ne derecede önemli olduğu halen tam olarak kanıtlanmış değildir. Yapılan birçok çalışmada sebze, meyve, C vitamini, kalsiyum desteği ve tahılların koruyucu rolü olduğu bulunmuş $(6,7)$, et ve yağlı yiyeceklerin 
riski arttırdığı tespit edilmiştir $(8,9)$. Bunların tersine birçok çalışmada besin grupları arasında anlamlı farklılıkların olmadığı da savunulmuştur $(10,11)$. Özel besin gruplarının hangi mekanizma ile kolon polipleri ve kolon kanseri oluşumuna etki ettikleri bilinmemektedir. Özellikle bitkisel besinlerin biyoaktif içeriklerinden dolayı antioksidan etki sağlayarak hücreleri DNA hasarından korudukları, karsinogenezi inhibe eden genleri aktive ettikleri üzerinde durulmaktadır. Tersine, düşük lif içerikli besinlerin antioksidan içerikleri daha düşüktür ve kolon transit süresini kısaltarak karsinogenez ve DNA hasarını hızlandııılar (12). Bu çalışmada prospektif olarak 2012-2015 yılları arasında Antalya Eğitim ve Araştırma Hastanesi Gastorenteroloji Kliniği'nde kolonoskopi yapılan hastalar diyet alışkanlıkları yönünden birebir ankete tabi tutuldu ve polip saptanan hastalar polip histolojisi ve boyutları da değerlendirilerek normal kolonoskopik bulgulara sahip hastalarla beslenme alışkanlıkları yönünden istatiksel olarak analiz edildi.

\section{GEREÇ ve YÖNTEM}

Çalışmamız prospektif anket çalışmasıdır. Etik kurul onayı Antalya Eğitim ve Ararştırma Hastanesi etik kurulundan alınmıştır (evrak no/tarih: 31-02/26.12.2013).

\section{Çalışma Popülasyonu}

Araştırma popülasyonunu Antalya Eğitim ve Araştırma Hastanesi Gastroenteroloji Kliniği'nde kolonoskopi yapılan hastalar oluşturmaktadır. Hastalar daha önce polip saptanması, kolon kanseri öyküsü, inflamatuvar barsak hastalığı tanısı olması ve geçirilmiş kolon operasyonu öyküsü olması durumunda araştırma popülasyonundan çıkarılmışıı. 2012-2015 yılları arasında kolonoskopisi yapılan ve araştırmaya katılmayı kabul eden 1004 hasta kolonoskopi sonrası birebir ankete tabi tutulmuştur. Hastalar poliplerin patolojik sınıflamasına göre (hiperplastik, adenomatöz, serrated) ve boyutlarına göre $<1 \mathrm{~cm}$ ve $>1$ $\mathrm{cm}$ olarak sınıflandırılmıştır.

\section{Diyet Alışkanlıklarının Değerlendirilmesi}

Hastaların beslenme ve yaşam tarzı bilgileri değerlendirilmek için Adventist Health Study tarafından geliştirilen food frequency questionnaire (FFQ) anketi kullanıldı (13) (Tablo 1). Demografik bilgiler, geçmiş tıbbi öykü ve psikososyal faktörler bu ankete dahil edildi. Katılımcılara her bir yiyecek ve içecek için ortalama ne sıkıkla tükettikleri soruldu. Genel et tüketimi ve et alt grupları (kırmızı, beyaz, balık), taze sebze, pişmiş sebze, meyve, kuruyemiş, baklagil, bulgur, pirinç, süt, peynir, yumurta gibi ana besin grupları tüketim sıklı̆ına göre ve ekmek ise buğday, çavdar ve kepek ekmeği olarak sınıflanmıştır.

\section{İstatistiksel Değerlendirme}

Tanımlayıcı istatistikler frekans, yüzde, ortalama (mean), standart sapma (SD) değerleri ile sunulmuştur. Kategorik değişkenler arasındaki ilişkilerin analizinde Fisher's Exact Test veya Pearson ki-kare testi kullanılmışıtır. Kategorik değişkenler arasındaki lineer ilişkiler için Linear by Linear Association Testi kullanılmıştır. Normallik testinde gruptaki örneklem sayısı 50'den küçük olduğunda Shapiro Wilks, büyük olduğunda Kolmogorov-Smirnov testi kullanılmıştır. İki grubun ölçüm değerleri arasındaki farkın analizinde normallik varsayımı Shapiro-Wilk testi ile kontrol edilmiş, normal dağılıma uymadığı durumda Mann-Whitney U testi, uyduğu durumda Student t testi kullanılmışır. Yapılan çapraz tablolar sonrasında ki-kare testleri anlamlı bulunan değişkenler tek değişkenli ve çok değişkenli lojistik regresyon analizlerine dahil edilmiştir. Sonuçlar Wald istatistiği, Odds Ratio ve \%95 güven araIıkları ile sunulmuştur. 0,05'den küçük $p$ değerleri istatistiksel olarak anlamlı kabul edilmiştir. Analizler SPSS 18.0 paket programı ile yapıımıştır.

\section{BULGULAR}

Toplam 1004 hastanın ortalama yaşı 52,17 olarak saptanırken popülasyon $423(\% 42,1)$ erkek, $581(\% 57,9)$ kadın hastadan oluşmaktaydı. $380(\% 31,1)$ hastada polip saptanırken $624(\% 68,9)$ hastada polip saptanmadı. Polip saptanan hastaların 112'sinde $(\% 29,5)$ hiperplastik polip saptanırken, $268(\% 70,5)$ hastada adenomatöz polip saptandı. Saptanan poliplerin $268(\% 70,5)$ tanesi 1 cm'den küçükken, $112(\% 29,5)$ tanesi 1 cm'den büyük olarak saptandı (Tablo 2).

Polip gelişimi, adenomatöz histoloji gelişimi ve polip boyutunu etkileyebilecek faktörler yapılan tek değişkenli analizlerle $p<0,05$ ya da çok yakın olmalarına göre saptandıktan sonra bu değişkenler çok değişkenli analiz ile değerlendirildi.

\section{Polip Gelişimini Etkileyen Faktörler}

Polip gelişimini etkileyen risk faktörleri olarak; artan yaş, erkek cinsiyet, kırmızı et, domates ve bulgur tüketimi bulundu $(p<0,05)$. Yaştaki her bir birimlik artışın polip görülme riskini artırdığı saptandı [Odds ratio $(O R)=1,049$ Confidence Interval $(\mathrm{Cl})=\% 95$ 1,034-1,063]. Hiç kırmızı et tüketmeyenlere göre haftada birden az kırmızı et tüketenlerde polip görülme sıklığı 3 kat (OR=3,016, Cl=\%95 $1,763-5,159)$, haftada birden çok tüketenlerde ise 10 (OR=10,819, Cl=\%95 5,900-19,841) kat artmaktaydı. Haftada 7'den çok domates tüketenlerde, haftada 4 adet domates tüketenlere göre polip OR 0,583 olurken, 
polip görülme riski 1,7 kat azalmaktaydı (Cl:\%95 0,3760,905). Ayda 1-3 kez bulgur tüketenlere göre haftada 1-2 kez bulgur tüketenlerde polip görülme riski 1,7 kat
( $\mathrm{OR}=1,730, \mathrm{Cl}=\% 95$ 1,157-2,586), haftada 2 'den çok tüketenlerde ise 8 kat artmaktaydı $(\mathrm{OR}=8,330 \mathrm{Cl}=\% 95$ 5,109-13,600) (Tablo 3).

\section{Tablo 1. Anket formu}

\section{ANTALYA EĞiTIM ARAŞTIRMA HASTANESI \\ iç HASTALIKLARI KLINIGGi \\ Kolon Polip Çalışma Formu}

Adı:

Tarih:

Soyadı:

Protokol numarası:

Yaş:

Cinsiyet:

Boy:

Kilo:

Vücut kitle indeksi:

1) $<18$

2) $18-25$

3) $>25$

Ailenizde polip saptanan kişi var mı?

1) $\mathrm{Var}$

Eğitim durumu:

1) Okur yazar değil

2) Yok

Fiziksel egzersiz:

1) Hiç

2) İlkokul-ortaokul-lise

3) Üniversite

Alkol kullanımı:

1) Hayır

2) Ara sira

3) Sik

Sigara kullanımı:

1) Hayır

2) Evet

Kabızlık:

1) Yok

2) Evet

Ağrı kesici kullanımı:

1) Hayır

2) $\mathrm{Var}$

Aspirin kullanımı:

1) Hayır

2) Evet

Vitamin desteği:

1) Hayır

2) Evet

Aşağıdaki besin çeşitlerini yeme sıklığınızı seçeneklere göre belirtiniz:

Toplam et tüketimi:

1) Hiç

2) Haftada birden az

3) Haftada birden çok

Beyaz et:

1) Hiç

2) Haftada birden az

3) Haftada birden çok

Kırmızı et:

1) Hiç

2) Haftada birden az

3) Haftada birden çok

Balık:

1) Hiç

2) Haftada birden az

3) Haftada birden çok

Salata:

1) Haftada 4 'ten $a z$

2) Haftada 4-7 arası

3) Haftada $7^{\prime}$ den çok

Pişmiş yeşil sebze:

1) Haftada $4^{\prime}$ ten az

2) Haftada 4-7 arası

3) Haftada 7'den çok

Domates:

1) Haftada 4 adet

2) Haftada 4-7 arası

3) Haftada 7'den çok

Baklagil:

1) Ayda bir kez

2) Ayda 1-4 kez

3) Haftada 1'den fazla

Kabuklu yemiş:

1) Haftada bir

2) Haftada 1-4 kez

3) Haftada 5 ya da daha çok

Meyve:

1) Haftada bir

2) Haftada 1-4 kez

3) Haftada 5 ya da daha çok

Bulgur:

1) Ayda 1-3 kez

2) Haftada 1-2 kez

3) Haftada 3 ve daha çok

Pirinç:

1) Ayda 1-3 kez

2) Haftada1-2 kez

3) Haftada 3 ve daha çok

Ekmek:

1) Beyaz ekmek

2) Çavdar ekmeği

3) Diğer

Peynir:

1) Hiç

2) Haftada 1-3 kez

3) Haftada 3 'den fazla

Süt:

1) Hiç

2) Haftada 1-7 arası

3) Günde birden fazla

Yumurta:

1) Hiç

2) Haftada 1-2 kez

3) Haftada 3 ya da daha çok 
Tablo 2. Hastaların polip durumuyla ilgili tanımlayıcı istatistikler

\begin{tabular}{|lccc|}
\hline Değişken & Kategori & $\mathbf{n}$ & $\%$ \\
\hline Polip & Yok & 624 & 60,9 \\
\hline Patoloji & Var & 380 & 31,1 \\
\hline & Hiperplastik & 114 & 29,5 \\
\hline Boyut & Adenomatöz & 266 & 70,5 \\
& Küçük 1 cm & 268 & 70,5 \\
& Büyük $1 \mathrm{~cm}$ & 112 & 29,5 \\
\hline
\end{tabular}

Tablo 3. Polip oluşumunu etkileyen bağımsız risk faktörleri

\begin{tabular}{|c|c|c|c|c|c|c|c|c|c|c|}
\hline \multirow{3}{*}{ Değişkenler } & \multicolumn{5}{|c|}{ Tek Değişkenli Analiz } & \multicolumn{5}{|c|}{ Tek Değişkenli Analiz } \\
\hline & \multirow{2}{*}{ Wald } & \multirow{2}{*}{$p$} & \multirow{2}{*}{ OR } & \multicolumn{2}{|c|}{$95 \% \mathrm{Cl}$} & \multirow{2}{*}{ Wald } & \multirow{2}{*}{$\mathbf{p}$} & \multirow{2}{*}{ OR } & \multicolumn{2}{|c|}{$95 \% \mathrm{Cl}$} \\
\hline & & & & Alt & Üst & & & & Alt & Üst \\
\hline Yaş & 34,830 & $<0,001$ & 1,031 & 1,021 & 1,042 & 46,147 & $<0,001$ & 1,049 & 1,034 & 1,063 \\
\hline Cinsiyet (erkek/kadın) & 4,335 & 0,037 & 1,321 & 1,016 & 1,717 & 12,260 & $<0,001$ & 1,868 & 1,317 & 2,650 \\
\hline Eğitim (lise ve altı) & 8,659 & 0,003 & 0,617 & 0,448 & 0,851 & 3,308 & 0,069 & 0,684 & 0,454 & 1,030 \\
\hline Ailede polip (var/yok) & 5,383 & 0,020 & 1,536 & 1,069 & 2,208 & 2,082 & 0,149 & 1,419 & 0,882 & 2,282 \\
\hline Kırmızı et (referans hiç) & 172,968 & $<0,001$ & & & & 66,701 & $<0,001$ & & & \\
\hline Kırmızı et (haftada 1 'den az) & 28,205 & $<0,001$ & 3,702 & 2,284 & 6,001 & 16,240 & $<0,001$ & 3,016 & 1,763 & 5,159 \\
\hline Kırmızı et (haftada 1'den çok) & 132,100 & $<0,001$ & 18,796 & 11,397 & 30,997 & 59,236 & $<0,001$ & 10,819 & 5,900 & 19,841 \\
\hline Domates (referans haftada 4 adet) & 6,389 & 0,041 & & & & 5,911 & 0,052 & & & \\
\hline Domates (haftada 4-7 adet) & 4,158 & 0,041 & 0,706 & 0,505 & 0,987 & 3,023 & 0,082 & 0,685 & 0,447 & 1,049 \\
\hline Domates (haftada 7'den çok) & $<0,001$ & 0,998 & 1,000 & 0,717 & 1,395 & 5,778 & 0,016 & 0,583 & 0,376 & 0,905 \\
\hline Bulgur (referans ayda 1-3 kez) & 189,676 & $<0,001$ & & & & 76,318 & $<0,001$ & & & \\
\hline Bulgur (haftada 1-2 kez) & 19,916 & $<0,001$ & 2,185 & 1,550 & 3,079 & 7,133 & 0,008 & 1,730 & 1,157 & 2,586 \\
\hline Bulgur (haftada 2'den çok) & 183,582 & $<0,001$ & 15,086 & 10,188 & 22,338 & 72,081 & $<0,001$ & 8,336 & 5,109 & 13,600 \\
\hline Beyaz et (referans hiç) & 14,922 & $<0,001$ & & & & 2,667 & 264 & & & \\
\hline Beyaz et (haftada birden az) & 7,210 & 0,007 & 2,868 & 1,329 & 6,189 & 2,519 &, 112 & 2,084 & 842 & 5,158 \\
\hline Beyaz et (haftada birden çok) & 12,158 & $<0,001$ & 4,022 & 1,839 & 8,794 & 1,725 & , 189 & 1,878 & ,733 & 4,808 \\
\hline
\end{tabular}

\section{Polip Histolojisini Etkileyen Faktörler}

Adenomatöz polip gelişimini etkileyen risk faktörleri; yaş, bulgur, pirinç ve yumurta tüketimi olarak bulundu $(p<0,05)$. Yaştaki her bir birimlik artışın adenomatöz polip görülme riskini artırdığı saptandı ( $\mathrm{OR}=1,043 \mathrm{Cl}=\% 95$ 1,030-1,056). Ayda 1-3 kez bulgur tüketenlere göre haftada 1-2 kez bulgur tüketenler adenomatöz polip görülme riskini 2 kat, haftada 2'den çok tüketenler ise 23 kat arttırmaktaydı (OR=2,628 Cl=\%95 1,790-3,858, $\mathrm{OR}=23.207 \mathrm{Cl}=\% 95$ 14,696-36,695). Ayda 1-3 kez pirinç tüketenlere göre haftada 1-2 kez pirinç tüketenlerde OR
0,636 saptanırken adenomatöz polip görülme riskinin 1,5 kat azaldığı, haftada 2'den çok tüketenlerde ise OR 0,403 saptanırken polip görülme riski 2,4 kat azalmaktaydı ( $p<0,05)$. Haftada 3'den fazla yumurta tüketen hastalarda hiç tüketmeyenlere göre adenomatöz polip görülme sıklığı 2,3 kat daha düşüktü ( $\mathrm{OR}=0,419, \mathrm{Cl}=\% 95$ 0,330-0,621, p<0,05) (Tablo 4).

\section{Polip Boyutunu Etkileyen Faktörler}

Tüm değişkenler bir arada incelendiğinde, Tablo 4.10'da görüldüğü gibi 1 cm'den büyük polip görülmedeki risk faktörü yalnızca bulgur tüketimi olarak bulundu $(p<0,05)$. 
Tablo 4. Polip histolojisini etkileyen bağımsız risk faktörleri

\begin{tabular}{|c|c|c|c|c|c|c|c|c|c|c|}
\hline \multirow{3}{*}{ Değişkenler } & \multicolumn{5}{|c|}{ Tek Değişkenli Analiz } & \multicolumn{5}{|c|}{ Tek Değişkenli Analiz } \\
\hline & \multirow{2}{*}{ Wald } & \multirow{2}{*}{ p } & \multirow{2}{*}{ OR } & \multicolumn{2}{|c|}{$95 \% \mathrm{Cl}$} & \multirow{2}{*}{ Wald } & \multirow{2}{*}{$\mathbf{p}$} & \multirow{2}{*}{ OR } & \multicolumn{2}{|c|}{$95 \% \mathrm{Cl}$} \\
\hline & & & & Alt & Üst & & & & Alt & Üst \\
\hline Yaş & 6,529 & 0,011 & 0,975 & 0,956 & 0,994 & 41,349 & $<0,001$ & 1,043 & 1,030 & 1,056 \\
\hline Aspirin (evet/hayir) & 5,178 & 0,023 & 0,537 & 0,315 & 0,917 & 0,061 & 0,804 & 0,952 & 0,645 & 1,406 \\
\hline Yumurta (haftada 3'den fazla) & 6,167 & 0,013 & 2,805 & 1,243 & 6,329 & 7,809 & 0,005 & 0,419 & 0,228 & 0,771 \\
\hline Baklagil (ayda 1-4 kez) & 7,667 & 0,006 & 2,305 & 1,276 & 4,163 & 0,022 & 0,883 & 0,969 & 0,635 & 1,478 \\
\hline Baklagil (ayda 1-4 kez) & 19,215 & $<0,001$ & 5,333 & 2,523 & 11,273 & 2,744 & 0,098 & 1,540 & 0,924 & 2,565 \\
\hline Bulgur (referans ayda 1-3 kez) & 69,462 & $<0,001$ & & & & 188,421 & $<0,001$ & & & \\
\hline Bulgur (haftada 1-2 kez) & 55,636 & $<0,001$ & 18,914 & 8,735 & 40,952 & 24,317 & $<0,001$ & 2,628 & 1,790 & 3,858 \\
\hline Bulgur (haftada 2'den çok) & 54,601 & $<0,001$ & 11,951 & 6,189 & 23,077 & 182,000 & $<0,001$ & 23,207 & 14,696 & 36,645 \\
\hline Pirinç (referans ayda 1-3 kez) & 16,528 & $<0,001$ & & & & 11,988 & 0,002 & & & \\
\hline Pirinç (haftada 1-2 kez) & 16,335 & $<0,001$ & 2,876 & 1,723 & 4,801 & 5,850 & 0,016 & 0,636 & 0,440 & 0,918 \\
\hline Pirinç (haftada 2'den çok) & 1,360 & 0,244 & 1,524 & 0,751 & 3,093 & 10,986 & 0,001 & 0,403 & 0,236 & 0,690 \\
\hline
\end{tabular}

Tablo 5. Polip boyutlarını etkileyen bağımsız risk faktörleri

\begin{tabular}{|c|c|c|c|c|c|c|c|c|c|c|}
\hline \multirow{3}{*}{ Değişkenler } & \multicolumn{5}{|c|}{ Tek Değişkenli Analiz } & \multicolumn{5}{|c|}{ Tek Değişkenli Analiz } \\
\hline & \multirow{2}{*}{ Wald } & \multirow{2}{*}{ p } & \multirow{2}{*}{ OR } & \multicolumn{2}{|c|}{$95 \% \mathrm{Cl}$} & \multirow{2}{*}{ Wald } & \multirow{2}{*}{ p } & \multirow{2}{*}{ OR } & \multicolumn{2}{|c|}{$95 \% \mathrm{Cl}$} \\
\hline & & & & Alt & Üst & & & & Alt & Üst \\
\hline Yaş & 5,508 & 0,019 & 0,976 & 0,956 & 0,996 & 0,220 & 0,639 & 0,995 & 0,972 & 1,018 \\
\hline Cinsiyet (kadın/erkek ) & 5,029 & 0,025 & 1,853 & 1,081 & 3,177 & 0,284 & 0,594 & 1,188 & 0,630 & 2,240 \\
\hline \multicolumn{2}{|c|}{ Domates (referans haftada 4 adet)9,779 } & 0,008 & & & & 6,029 & 0,049 & & & \\
\hline Domates (haftada 4-7 adet) & 5,598 & 0,018 & 0,405 & 0,192 & 0,856 & 3,374 & 0,066 & 0,446 & 0,188 & 1,056 \\
\hline Domates (haftada 7'den çok) & 0,342 & 0,559 & 1,199 & 0,653 & 2,202 & 0,144 & 0,704 & 1,151 & 0,558 & 2,374 \\
\hline Bulgur (referans ayda 1-3 kez) & 40,882 & $<0,001$ & & & & 27,215 & $<0,001$ & & & \\
\hline Bulgur (haftada 1-2 kez) & 0,268 & 0,605 & 0,650 & 0,128 & 3,319 & 0,068 & 0,795 & 0,802 & 0,152 & 4,241 \\
\hline Bulgur (haftada 2'den çok) & 18,330 & $<0,001$ & 13,648 & 4,125 & 45,155 & 15,133 & $<0,001$ & 13,234 & 3,602 & 48,622 \\
\hline
\end{tabular}

Buna göre, haftada 2'den çok bulgur tüketenlerde ayda 1-3 kez tüketenlere göre 13 kat daha fazla $1 \mathrm{~cm}$ 'den büyük polip görülmekteydi ( $O R=13,234, C l=\% 95, p<0,001)$ (Tablo 5).

Sonuç olarak tüm faktörler göz önüne alındığında çalışmamızda kolon polip gelişmesini yaş, erkek cinsiyet, kırmızı et ve bulgur tüketimi arttıırken, domates tüketimi azaltmaktaydı. Adenomatöz histoloji görülme sıklığını artıran faktörler yaş ve bulgur tüketimi olarak saptanırken, azaltan faktörler ise yumurta ve pirinç tüketimindeki artış olarak saptandı. Kolon polip boyutlarını ise sadece bulgur tüketimindeki artışın etkilediği görüldü.

\section{TARTIŞMA}

Adenomatöz polipler KRK için öncü lezyonlardır. KRK'e yaşam boyunca yakalanma riski \%2,6 olup, polipektomi tekniklerindeki gelişmeleri takiben KRK insidansı azalmıştır. 1 cm'den küçük bir polipte KRK gelişimi için ortalama 10 yıl gereklidir. KRK gelişiminde polip varlığı, polibin histolojisi ve boyutu risk belirlemede en önemli faktörleri oluşturmaktadır (1).

\section{Kolon Polip Varlığı ve Değişkenlerin Tartışması}

Artan kanser sıklığı ve olumsuz çevresel faktörler göz önüne alındığında yakın gelecekte kolon kanserinin pre- 
valansında ve mortalitesinde artış beklenmektedir. KoIon kanserinden korunmada polipleri saptamak ve daha önemlisi diyet alışkanlıklarımızı düzenleyerek polip gelişimini engellemek en önemli basamağı oluşturmaktadır.

ABD'de yapılan bir otopsi çalışmasında kolon polip prevalansının \%50 (14), kolonoskopi ile yapılan çalışmalarda ise \%40'a kadar yükselen polip görülme sıklı̆̆ı tespit edilmiştir $(15,16)$. Benzer şekilde çalışmamızda polip görülme sıklığı \%34,9, erkeklerde \%39,5 kadınlarda \%31,1 di.

Shinya ve arkadaşlarının yaptığı çalışmada tespit edilen poliplerin \%90'dan fazlası epitel kökenli olup bunların $\% 75^{\prime} i$ adenomatöz ve $\% 25^{\prime} i$ hiperplastiktir (17). Çalışmamızda ise adenomatöz polipler $\% 70$, hiperplastik polipler ise \%30 oran ile literatüre paralellik göstermekteydi.

$1 \mathrm{~cm}$ 'den küçük polipler yapılan çalışmalarda $1 \mathrm{~cm}$ 'den büyük poliplere göre 2-3 kat daha sık saptanmıştır $(18,19)$. Sonuçlarımıza bakıldığında ise bu oran $1 \mathrm{~cm}$ 'den küçük poliplerde \%70,4 iken, 1 cm'den büyük poliplerde $\% 29,6$ idi.

Dünya genelinde beslenme alışkanlıkları son yıllarda özellikle dondurulmuş, hazır gıdalar ve fast-food tarzı beslenme nedeniyle değişmekte olup, bitkisel ve doğal olan besin ürünlerinden uzaklaşılmaktadır. Bu tablo Türkiye gibi gelişmekte olan ülkelerde daha hızlı ilerlemekte olup, çalışmamızı yaptığımız Antalya gibi seracılığın, bitkisel ürün yetiştiriciliğinin ve akdeniz tipi beslenmenin yaygın olduğu bir şehirde bile etkilerini göstermektedir. Değişen diyet alışkanlıkları; kabızlık, dispeptik şikayetler, irritabl barsak sendromu (IBS), kolon polipleri ve kolorektal kanser için risk oluşturmaktadır $(20,21)$.

John S.ve arkadaşlarının yaptığı vaka kontrol çalışmasında 488 adet kolonoskopi yapılan hastanın diyet alışkanlıkları sorgulandığında sebze, meyve ve tahıl tüketiminin kolorektal poliplere karşı koruyucu olduğu saptanmıştır (21). Alfred I. yaptığı çalışmada 162 kadın 124 erkek toplam 286 adet adenomatöz polibi olan hastanın beslenme düzenlerini karşılaştırmış ve erkeklerde beslenme düzeni ile adenomatöz polip varlığı arasında ilişki saptanmazken, kadınlarda doymuş yağ tüketiminin adenomatöz polip görülme sıkıı̆ını arttırdığını saptamıştır. Kırmızı etin, beyaz et ve balığa göre polip riskinde artmış risk taşıdığı saptanırken bunun tam tersine beyaz et ve balığın adenomatöz polip gelişiminde koruyucu oldukları saptanmıştır. Sebze tüketimi, aspirin, C vitamini ya da non-steroid antiinflamatuvar ilaç (NSAii) kullanımı ile herhangi bir ilişki saptanmamıştır (22). Lanza ve arkadaşlarının yaptığı çalışmada ise 405 hasta yüksek fiber (18 g/1000 kcal), düşük yağ (total enerjinin \%20'si), yüksek meyve-sebze (3,5 porsiyon/1000 kcal) ile beslenmiş, 392 hasta nor- mal diyet ile beslenmiş ve 8 sene prospektif olarak takip edilmiştir. Çalışma sonunda yapılan kolonoskopi sonuçlarında iki grup arasında polip gelişimi ile düşük yağ-yüksek fiber-sebze ve meyve ile beslenme arasında herhangi bir bağlantı saptanmamıştır (23).

Görüldüğü üzere literatür beslenme ve kolon polibi gelişme konusunda çelişkili bilgiler içermektedir. Çalışmamızda ise polip gelişimini artıran besin ürünleri olarak kırmızı et ve bulgur tüketiminin ön plana çıktığı, domates tüketiminin artmasıyla polip görülme sıklığının azaldığı saptanmıştır ( $p<0,05)$. Bu noktada özellikle bulgur tüketimi ile ilgili çarpıcı sonuçlar görülmektedir. Bulgur tahıl grubuna dahil bir üründür ve tam tahıl olarak geçmektedir. Fiber içerikli besinler içinde "çözünmeyen fiberler" grubundadır ve hemisellilöz bir üründür. Kolon transit süresini kısaltarak etki gösterir (23). Bu etkileri gözönüne alındığında bulgur kolon transit süresini kısaltarak fekal karsinojenlerle ve safra asitleriyle barsak duvarının temas süresini kısaltarak kolon kanserine karşı koruyucu olabileceğini düşündürse de; sonuçlarımızda bulgur tüketiminin artmasıyla kolon polip gelişimi riski arasındaki belirgin lineer artış düşündürücüdür ve daha detaylı araştırılması gereken bir konudur.

\section{Kolon Polip Histolojisi ve Değişkenlerin Tartışması}

İtalya'da yapılan bir çalışmada sıkı akdeniz diyeti ile beslenen 314 kişinin poliplerinin histolojisi incelenmiş ve adenomatöz poliplerin sadece 1,5 kat daha sık görüldüğü saptanmıştır (24). Çalışmamızda kolorektal adenomatöz polipleri hiperplastik poliplerden 3 kat daha sık saptadığımı düşünüldüğünde bu durumun literatür ile uyumlu olduğunu söyleyebiliriz. Fakat Türkiye'de Antalya'nın akdeniz diyetiyle beslenme konusunda üst sıralarda olan bir şehir olduğu düşünüldüğünde beklenenden daha sık adenomatöz polip saptadığımız sonucuna varılabilir ve bu konuda beslenme düzenimizdeki değişimler, özellikle batı tipi beslenmeye doğru olan değişimimiz ve sebze-meyve üretiminde kullanılan hormonal preparatların etkisi düşündürücüdür.

Yapılan çalışmalar genelde adenomatöz polipler konusunda olup özellikle son dekadda hiperplastik ve adenomatöz polipleri karşılaştıran çalışmalar yapılımışır. Juergen ve arkadaşlarının Almanya'da yaptıkları vaka kontrol çalışmasında 207 adenomatöz polipli, 77 hiperplastik polipli ve 277 adet polibi olmayan hasta sigara-alkol kullanımı, beslenme alışkanlıkları ve kullandıkları ilaçlar yönünden karşılaştırılmış. Yapılan çok değişkenli analizlerde yaş, erkek cinsiyet ve sigara tüketimi ile anlamlı risk artışı saptanmıştır. Hiperplastik polip gelişimi ile ilgili yapılan 
çok değişkenli analizlerde ise salam-sosis tüketimi ve erkek cinsiyetin hiperplastik polip gelişiminde risk faktörü oldukları saptanmışıı (25).

Çalışmamızda ise adenomatöz polip gelişimini etkileyen risk faktörleri olarak yaş, bulgur, pirinç ve yumurta tüketimi bulundu.

Bulgur tüketiminin polip görülme sıklığında meydana getirdiği artış da göz önüne alındığında adenomatöz poliplerde de görülen bu risk artışı düşündürücüdür. Kolon kanserinin özellikle adenomatöz histolojideki poliplerden gelişiyor olması bulgur tüketimini prekanseröz lezyon gelişiminde çok önemli bir noktaya getirmektedir.

\section{Kolon Polip Boyutu ve Değişkenlerin Tartışması}

Çoğu polip $1 \mathrm{~cm}$ 'den küçüktür fakat poliplerin boyutu hastaların yaşı ve poliplerin kolonda yerleşme yerine göre değişkenlik gösterir. Bir otopsi çalışmasına göre poliplerin \%13-16'sı 1 cm'den büyüktür. Küçük polipler genel olarak kolon girişinde yer alırlarken büyük polipler ise daha proksimal yerleşimlidir (16). Prospektif çalışmalarda ise proksimal yerleşimli adenomatöz polipler \%24-34 oranında görülmüş olup 5 mm'den daha büyük poliplerdir (25). Suminori ve arkadaşları tarafından yapılan bir çalışmada düşük pirinç tüketimi ve yüksek et tüketiminin adenomatöz poliplerin boyutlarını büyüterek kolon kanseri gelişiminde risk faktörü olabileceği belirtilmiştir $(25,26)$. Literatürde özellikle kolon polip boyutlarını etkileyen faktörlerle ilgili yapılmış çalışma sınırlı sayıda olup çalışmamızda ise 1 cm'den büyük polip görülmesindeki risk faktörü yalnızca bulgur tüketimi olarak bulundu $(p<0,05)$.

Çalışmamızda kolonda polip gelişimi, adenomatöz histoloji varlığı ve $1 \mathrm{~cm}$ den büyük polip gelişimi şeklinde bu üç kolorektal kanser risk faktörünü de arttıran tek besin maddesi bulgur olarak saptandı. Bulgur tahıl grubuna dahil bir üründür, buğdaydan yapılmaktadır ve tam tahıl olarak geçmektedir. Fiber içerikli besinler içinde "çözünmeyen fiberler" grubundadır ve hemisellilöz bir üründür. Kolon transit süresini kısaltarak etki gösterir (24). Genel bilgi olarak içerdiği düşük protein-yüksek karbonhidrat, selenyum-çinko ve yüksek lif içeriği kolon kanserinden koruyucu olarak bilinmektedir. Özellikle son yıllarda artan nüfusun besin intiyaçlarını karşılamak için genetiği değiştirilmiş ürünler (GDÜ) geliştirilmiştir ve bulgur da bu durumdan etkilenen ürünlerden biridir. GDÜ'lerle ilgili uzun süreli deneyimimiz olmayıp son dekadda toksik etkileri hakkında yapılmış çok sayıda yayın mevcuttur. Bu duruma ek olarak bulgurun iyi kurutulmaması ya da nemli yerlerde saklanması sonucu küflenmeye ve aflatoksin, okratoksin ve patulin miktarında artışa yol açabilir. Bulgur posasının kolon lümeninde uzun süre kalması bildiğimiz ya da henüz bilmediğimiz toksinler ve karsinojenler aracllığıyla kolonda polip oluşmasına yol açabileceği düşünülebilir. Bulgurun etkisiyle oluşan bu poliplerin adenomatöz histolojide olması ve $1 \mathrm{~cm}$ 'den büyük polipler gelişmesi bulgurun etkisini daha da önemli hale getirmektedir. Çaış̧mamızda beyaz ekmek gibi diğer buğday ürünlerinde aynı ilişkiyi saptamamamı ise bu ürünlerin posasından tamamen ayrılarak un halindeyken yapılması ve yüksek ısıya maruziyet sonrası küflenme riskinin ortadan kalkması ile açıklanabilir ve bu durum hipotezimizi destekler niteliktedir.

\section{SONUÇ}

Çalışmamızda saptadığımız yaşın ilerlemesi ile artan koIon polip sıklığı ve adenomatöz histoloji varlığı, beklenen ve literatürle paralellik gösteren bir bulguydu. Fakat bulgur tüketimi arttıkça anlamlı şekilde kolon polip görülme sıklığının artması, adenomatöz histoloji sıklığının artması ve $1 \mathrm{~cm}$ 'in üstü boyutta daha sık polip görülmesi ve tüm bu etkenlerin aynı zamanda kolon kanseri için de risk faktörü olduğu gözönüne alındığında bulgurun tüketim şekli, sıklığı ve kolon kanseri saptanan hastaların geçmiş dönemdeki bulgur tüketimleri ayrıntılı sorgulanmalı ve bu konuyla ilgili daha ayrıntılı çalışmalar yapılmalıdır. Değişen beslenme düzenimiz, GDÜ'ler, yetiştirme sırasında kullanılan kimyasal maddeler, besinler bize ulaşana kadar saklama koşulları ya da değişen tüketim şekillerimiz göz önüne alındığında artık en güvenilir dediğimiz besin ürünlerinin bile kanserojen olabileceği akılda tutulmalı, besin maddelerine şüpheci yaklaşmalı ve kapsamlı araştırmalar ile sorunun nerede olduğunu geç olmadan saptamalıyı.

\section{KAYNAKLAR}

1. Longo DL. Approach to the patient with cancer. In: Fauci AS, Braunwald E, Kasper DL, eds. Harrison's Principles of Internal Medicine. 17th ed. New York: McGraw-Hill Professional; 2008.

2. Neri E, Giusti P, Battolla L, et al. Colorectal cancer: role of CT colonography in preoperative evaluation after incomplete colonoscopy. Radiology 2002;223:615-9.

3. Schor S, Behar S, Modan B, et al. Disposition of presumed coronary patients from an emergency room: a follow-up study. JAMA 1976;236:941-3.

4. Armstrong B, Doll R. Environmental factors and cancer incidence and mortality in different countries, with special reference to dietary practices. Int J Cancer 1975;15:617-31. 
5. Kono S, Ahn Y. Vegetables, cereals and colon cancer mortality: long-term trend in Japan. Eur J Cancer Prev 2000;9:363-5.

6. Neugut Al, Garbowski G, Lee WC, et al. Dietary risk factors for the incidence and recurrence and recurrence of colorectal adenomatous polyps. Ann Internal Med 1993;118:91-5.

7. Witte JS, Longnecker M, Bird CL, et al. Relation of vegetable, fruit and grain consumption to colorectal adenomatous polyps. Am J Epidemiol 1996;144:1015-25.

8. MacLennan R, Macrae F, Bain C, et al; Australian Polyp Prevention Project. Randomized trial of intake of fat, fiber, and beta carotene to prevent colorectal adenomas. J Natl Cancer Inst 1995;87:17606.

9. Hofstad B, Almendingen $K$, Vatn $M$, et al. Growth and recurrence of colorectal polyps: a double-blind 3-year intervention with calcium and antioxidants. Digestion 1998;59:148-56.

10. [No authors listed] Guidelines on diet, nutrition, and cancer prevention: reducing the risk of cancer with healthy food choices and physical activity. The American Cancer Society 1996 Advisory Committee on Diet, Nutrition, and Cancer Prevention. CA Cancer J Clin 1996;46:325-41.

11. Glade MJ. Food, nutrition, and the prevention of cancer: a global perspective. American Institute for Cancer Research/World Cancer Research Fund, American Institute for Cancer Research, 1997. Nutrition 1999;15:523-6.

12. Austin GL, Adair LS, Galanko JA, et al. A diet high in fruits and low in meats reduces the risk of colorectal adenomas. J Nutr 2007;137:999-1004.

13. Butler TL, Fraser GE, Beeson WL, et al. Cohort profile: the Adventist health study-2 (AHS-2). Int J Epidemiol 2008;37:260-5.

14. Shinya H, Wolff WI. Morphology, anatomic distribution and cancer potential of colonic polyps. Ann Surg 1979;190:679-83.

15. Lanza E, Hartman T, Albert PS, et al. High dry bean intake and reduced risk of advanced colorectal adenoma recurrence among participants in the polyp prevention trial. J Nutr 2006;136:1896903.

16. Edwards BK, Ward E, Kohler BA, et al. Annual report to the nation on the status of cancer, 1975-2006, featuring colorectal cancer trends and impact of interventions (risk factors, screening, and treatment) to reduce future rates. Cancer 2010;116:544-73.
17. O'brien MJ, Winawer SJ, Zauber AG, et al; National Polyp Study Workgroup. Flat adenomas in the National Polyp Study: is there increased risk for high-grade dysplasia initially or during surveillance? Clin Gastroenterol Hepatol 2004;2:905-11.

18. Leggett BA1, Devereaux B, Biden K, et al. Hyperplastic polyposis: Association with colorectal cancer. Am J Pathol 2001;25:177-84.

19. DeCosse JJ, Miller HH, Lesser ML. Effect of wheat fiber and vitamin- $C$ and vitamin-E on rectal polyps in patients with familial adenomatous polyposis. J Natl Cancer Inst 1989;81:1290-7.

20. Tantamango YM, Knutsen SF, Beeson WL, et al. Foods and food groups associated with the incidence of colorectal polyps: the Adventist Health Study. Nutr Cancer 2011;63:565-72.

20. Witte JS, Longnecker MP, Bird CL, et al. Relation of vegetable, fruit, and grain consumption to colorectal adenomatous polyps. Am J Epidemiol 1996;144:1015-25.

21. Neugut Al, Garbowski GC, Lee WC, et al. Dietary risk factors for the incidence and recurrence of colorectal adenomatous polyps: a case-control study. Ann Intern Med 1993;118:91-5.

22. Lanza E, Yu B, Murphy G, et al; Polyp Prevention Trial Study Group. The polyp prevention trial continued follow-up study: no effect of a low-fat, high-fiber, high-fruit, and -vegetable diet on adenoma recurrence eight years after randomization. Cancer Epidemiol Biomarkers Prev 2007;16:1745-52.

23. Erhardt JG, Kreichgauer HP, Meisner C, et al. Alcohol, cigarette smoking, dietary factors and the risk of colorectal adenomas and hyperplastic polyps-a case control study. Eur J Nutr 2002;41:35-43

24. Giovannucci E, Stampfer MJ, Colditz G, et al. Relationship of diet to risk of colorectal adenoma in men. J Natl Cancer Inst 1992;84:91-8

25. Kono S, Imanishi K, Shinchi K, Yanai F. Relationship of diet to small and large adenomas of the sigmoid colon. Jpn J Cancer Res 1993;84:13-9.

26. Ferlitsch M, Reinhart K, Pramhas $S$, et al. Sex-specific prevalence of adenomas, advanced adenomas, and colorectal cancer in individuals undergoing screening colonoscopy. JAMA 2011;306:1352-8. 